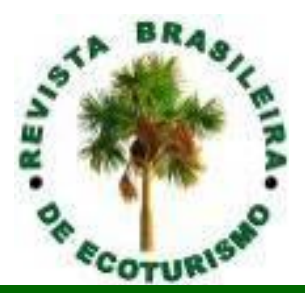

\title{
A protocol to evaluate the potential of protected areas for birdwatching tourism: a study case in the Brazilian Amazon
}

\section{Um protocolo para avaliar o potencial de áreas protegidas para o turismo de observação de aves: um estudo de caso na Amazônia Brasileira}

Ricardo Antônio de Andrade Plácido, Edson Guilherme, Sérgio Henrique Borges

\begin{abstract}
Birdwatching is a growing segment of ecotourism and South America's protected areas have an enormous potential to contribute to the development of this activity. We present a simple protocol to assess the potential of protected areas to attract and receive birdwatchers. The protocol is based on the application of raw scores using the following criteria: i) potential of local avifauna to attract birdwatchers, ii) logistic facilities of the protected area, and iii) services for accommodation, communication, health support and transport available in the municipality/ies located near the protected area. The protocol was applied in a protected area located in the State of Acre, in the southwestern part of the Brazilian Amazon. Thirty bird species (11\% of avifauna) achieved the highest level of attractiveness for birdwatchers. The protected area and its neighboring municipalities show median capacity for hosting birdwatchers. The application of the protocol in other protected areas will be necessary to improve its applicability. The method, however, could be useful for a preliminary analysis of the birdwatching potential of protected areas.
\end{abstract}

KEYWORDS: Protected Area; Ecotourism; Birdwatching.

RESUMO: A observação de aves é um crescente segmento do ecoturismo e as áreas protegidas da América do Sul têm um enorme potencial para contribuir para o desenvolvimento dessa atividade. Apresentamos um protocolo simples para avaliar o potencial da área protegida para atrair e receber observadores de aves. O protocolo baseia-se na aplicação de pontuações brutas usando os seguintes critérios: i) potencial da avifauna local para atrair observadores de aves, ii) instalações logísticas da área protegida e iii) serviços de acomodação, comunicação, apoio à saúde e transporte disponíveis no (s) município (s) localizados perto da área protegida. O protocolo foi aplicado em uma área protegida localizada no estado do Acre, sudoeste da Amazônia brasileira. Trinta espécies de aves (11\% da avifauna) alcançaram o nível mais alto de atratividade para observadores de aves. A área protegida e seus municípios vizinhos mostram capacidade mediana para acolher observadores de aves. A aplicação do protocolo em outras áreas protegidas será necessária para melhorar sua aplicabilidade. $\mathrm{O}$ método, no entanto, pode ser útil para uma análise preliminar do potencial de observação de aves em áreas protegidas.

PALAVRAS CHAVE: Áreas Protegidas; Ecoturismo; Observação de Aves. 


\section{Introduction}

The creation and management of official protected areas are the main strategies for protection of the Amazon, the largest tropical biome of the world. Over recent decades, a complex and extensive network of protected areas with different management goals has been implemented in the countries that comprise the Amazon rainforest (RAISG, 2017).

Conservation units ${ }^{1}$, for example, now represent $27 \%$ of the Brazilian Amazon, an area covering approximately 112 million hectares (ARAÚJO; BAIMA; GOMES, 2016). Furthermore, the Brazilian system of protected areas divides protected areas into multiple categories. Amongst these are protected areas where the use of natural resources by local communities is permitted (e.g., Extractive Reserves), and those with more restrictive access, where only research, educational and tourism activities are permitted and incentivized (e.g., National Parks).

There is an increasing trend in the use of natural areas for recreational activities in Brazil, and existing protected areas have an enormous potential to meet this demand in several ways (CARNICELLIFILHO et al., 2010; MEDEIROS et al., 2011). However, few studies have analysed the capacity of protected areas in the Brazilian Amazon to receive visitors and to develop specialized tourism activities, such as birdwatching (BERNARDON; NASSAR, 2012).

Birdwatching is a growing segment of ecotourism (EUBANK; STOLL; DITTON, 2004), and South America has enormous potential to develop this activity since the region houses the highest bird diversity in the world (STEVEN et al., 2015). Birdwatchers normally want to improve their personal list of observed species (life lists), which motivates them to search for endemic species in new areas (BONTA, 2010; PUHAKKA et al., 2011). For a rewarding and enjoyable experience, however, birdwatchers require basic logistic facilities, such as comfortable places to sleep, vehicles for transportation, and trails to access different habitat patches to observe birds. Moreover, the visiting sites must possess avifaunal components that interest birdwatchers (e.g., endemic species, birds with beautiful plumage and unusual behaviours, etc.).

Protected areas are likely to be important destinations for tourists interested in birdwatching. Indeed, the most important places to observe birds in Unites States and Brazil are located within the limits of protected areas (FARIAS, 2006; HEIMBUCH, 2015). Therefore, it is expected that Amazonian protected areas will be highly attractive destinations for birdwatchers. The capacity of such protected areas to receive tourists, however, is highly variable. Some of these areas are easily accessed and are in possession of good visitor-friendly conditions and facilities, while others are in remote regions and have poor logistic support to visitors. In addition, preliminary inventories of bird species recorded in a protected area will be useful to ascertain the potential of local avifauna to attract birdwatchers' attention. Such evaluations can provide relevant information for managers seeking to improve the tourism activities inside the protected areas under their responsibility. 
Here we present a simple protocol aimed at allowing the evaluation of the potential of protected areas in the Amazon region to received visitors interested in birdwatching. We tested the protocol in an area located in the State of Acre, a region that houses a great diversity of bird species (GUILHERME, 2016).

We expect that this protocol will prove to be useful in evaluating the potential for birdwatching in other protected areas and contribute to the consolidation of birdwatching-based tourism as a management strategy for Amazonian protected areas.

\section{Methods}

\section{Protocol description}

The protocol is based on three components: i) potential of the local avifauna to attract the attention of birdwatchers, ii) logistic facilities found throughout the interior of protected area, and iii) capacity of the municipality/ies located near the protected area to provide services of accommodation, health support in emergency situations and transport facilities to-and-from the protected area (e.g., rent of vehicles). For each of these components we identified specific criteria evaluated through a scoring system described below.

\section{Local Avifauna}

We used three indicators to evaluate the attractiveness of each bird species: geographic distribution, morphology and behaviour. The raw scores applied to bird morphology and behaviour had equal weights, but we put more weight on the geographic distribution criterion. We opted for this unequal weighting procedure because endemism is a major motivation for birdwatchers when choosing places to visit (BONTA, 2010; PUHAKKA et al., 2011).

The Amazon basin was divided into four major sectors using the opposing banks of the Negro and Madeira rivers (1852) to apply the raw scores for geographic distribution. The Madeira and Negro rivers were used due to their strong influence on the delimitation of areas of endemism for birds in the Amazon region (CRACRAFT, 1985). We used maps available in field guides of South American birds (PERLO, 2009; RIDGELY; TUDOR, 2009) to apply this criterion. Raw scores were assigned species-by-species in the following manner: i) species occurring in all four sectors of the Amazon basin (score 0), ii) species recording in three sectors of the basin (score 2), iii) species recorded in two sectors of the basin (score 4), and iv) species with a distribution restricted to only one sector of the Amazon basin (score 6).

Score application for bird morphology and behaviour was more subjective due to the nature of these indicators. We evaluated plumage and other morphological attributes, such as their beaks, iris, and other differentiated structures. Score distribution for morphology was applied using the following steps: i) species with uniform plumage lacking distinctive colour or other morphological attribute (score 0 ), ii) species with subtle variation in

541 Revista Brasileira de Ecoturismo, São Paulo, v.14, n.4, nov 2021-jan 2022, pp. 539-553. 
plumage colour or in other body parts (score 1), iii) species with noticeable plumage with variable colour pattern (score 2), and iv) species that, in addition to variable plumage colour, have some special attribute such as large tail feathers or coloured bills (raw score 3).

Score application for behaviour indicator focused on bird social behaviours, especially those associated with reproduction and feeding. Score application considered: i) solitary species without any behaviour that catches the observer's attention (score 0), ii) solitary species that exhibit attracting behaviours, such as acrobatic jumps (score 1), iii) species observed in mixed flocks, army ants' followers, or visitors to salt licks (score 2), and iv) species with highly elaborated social behaviours, including lekking behaviours (score 3).

To obtain a final score of each analysed species, we added the raw scores obtained from each of the three indicators. Then, an attractiveness quotient was calculated for each species in the following manner: species with low attractiveness ( 0 to 3 points), species with medium attractiveness (4 to 7 points) and highly attractive species (values $>8$ points).

To calibrate our method, we sent a checklist containing a subsample of bird species recorded in the studied area (see below) to 20 Brazilian birdwatchers from seven states of Brazil asking each participant to classify the listed species as low, median or high interest. Our birdwatchers sample included 10 women and 10 men with ages varying from 21 to 74, most with average to advanced experience in the birdwatching practice. We used two approaches to compare the datasets. First, we chose the simple majority (i. e., $50 \%+1$ ) of the surveyed answers and gave a determined score category (i. e., low, medium or high attractive) to a species. Complementary, we used the score category chosen by more than $70 \%$ of the surveyed. We analysed the degree of concordance between the birdwatchers' opinions with our own ranking using a $\mathrm{G}$ test of association (ZAR, 1996).

\section{Protected area logistic conditions}

The objective of this component was to identify the logistic conditions available in the protected area in terms of accessibility, trails, accommodation, and safety. The score gave equal weight to all indicators and its application followed the procedure described below.

-Access trails: i) protected area does not have access trails (score 0), ii) protected area has few and short trails without maintenance (score 1), iii) the protected area has long trails, however, these give limited access to the different habitat types found in the region (score 2), iv) presence of several trails that cross the main habitat types, are well signed, and receive regular maintenance (score $3)$.

- Accommodation infrastructure: i) the institution responsible for the protected area management does not maintain any accommodation infrastructure within the limits of protected area (score 0), ii) although the managing institution does not maintain any local infrastructure, the local people can provide basic accommodation (score 1), iii) the managing institution maintains a minimum infrastructure in the protected area that is used mainly by the management team, but could eventually be used by visitors (score 2), iv) the managing institution 
maintains a local infrastructure specially designed for the reception and accommodation of visitors (score 3).

- Communication services: i) there is no communication service available inside the protected area (score 0 ), ii) communication is only available via radio (score 1), iii) cell phone signal access is possible within the limits of the protected area (score 2), and iv) the protected area has a good communication apparatus, including cell phone signal, internet and radio (score 3 ).

-Public visitation monitoring: i) there are no control mechanism or monitoring of public visitation inside the protected area (score 0), ii) the managers know that the protected area is regularly visited, but no specific mechanism of visitor control are applied within the protected area (score 1), iii) managers adopted some form of monitoring protocol for public visitation, but they are not efficient (score 2), iv) the protected area has a simple and efficient monitoring visitation system where the visit statistics are used to improve the services of accommodation and trails services within the protected area (score 3).

- Availability of local guides: i) there are no guides available to help visitors on the protected area (score 0), ii) there are some local guides that know the region, but they do not have formal training in receiving visitors nor do they have a specific knowledge of the local avifauna (score 1), iii) there are local guides that have some training in receiving and guiding visitors (score 2), iv) there are guides with basic knowledge of local avifauna who can meet the requirements of visiting birdwatchers (score 3)

The final score for this component was obtained by adding the raw scores of the indicators. The potential of the protected area to receive birdwatchers was then categorized as: low capacity to receive birdwatchers (raw scores from 0 to 4), medium capacity for reception (raw scores from 5 to 9), and strong capacity to receive birdwatchers (raw scores from 10 to 15).

\section{Municipalities logistic capacity}

In this component we evaluated the logistic support and services offered in the municipality/ies adjacent to the protected area to support the birdwatching activities. We emphasize that this evaluation is not a complete and detailed touristic analysis of the cities, but only a simplified inventory of services available for birdwatchers.

-Proximity and accessibility to the protected area: i) there is no municipality near the protected area (score 0), ii) there are towns or cities near the protected area, but access to them is restricted (score 1), iii) there are municipalities near the protected area and the access is easy (score 2), iv) the access to protected area from the towns and cities is easily made via terrestrial or aquatic routes (score 3).

- Lodging facilities available: i) there are no hotel or lodges in the municipality (score 0), ii) there are few lodging options and none offering additional services (e.g., internet) (score 1), iii) there are several hotel options offering services such as internet, car rental and meals (score 2), iv) there is accommodation designed to meet the specific demands of birdwatchers, such as meals at various times, local guides and transport to the birding sites (score 3).

- Time spent from the lodges to birding spots: i) lodges are located more than 5 hours from good spots for birding within the protected area (score 0), ii) accommodations lies between 3 to 5 hours from good birding spots (score 1), iii)

543 Revista Brasileira de Ecoturismo, São Paulo, v.14, n.4, nov 2021-jan 2022, pp. 539-553. 
accommodation lies only 1 hour from birding spots (score 2), iv) good birding spots lie less than 1 hour from accommodation (score 3).

- Availability of field guide services: i) there are no guide specialized in the avifauna of the protected area (score 0), ii) there are guides living in regions distant from the protected area (score 1), iii) there are few local guides living in regions near the protected area (score 2), iv) there are several guides resident in the municipality near the protected area (score 3).

- Health services: i) the municipality does not provide basic health support services such as hospitals (score 0), ii) basic health support are available in the towns and cities near the protected area (score 1), iii) the municipality has good health services, adequate for the emergency needs of birdwatchers (score 2), iv) health services available in the municipality are able to attend more complexes situations, such as emergence surgery (score 3).

-Means of transportation: i) the only available means of transportation is vehicles rented in locations far from the protected area (score 0), ii) local people can rent such vehicles as car or boats (score 1), iii) means of transportation can be rented from local peoples and at least one company (score 2), iv) there are several options to rent vehicles provided by local people and companies (score $3)$.

As in the previous assays, the potential of the municipalities near the protected areas for hosting birdwatchers was categorized as: low capacity for receiving and hosting birdwatchers (raw scores 0 to 5), median capacity for hosting (raw score 6 to 12), and good hosting capacity (raw scores $>12$ ).

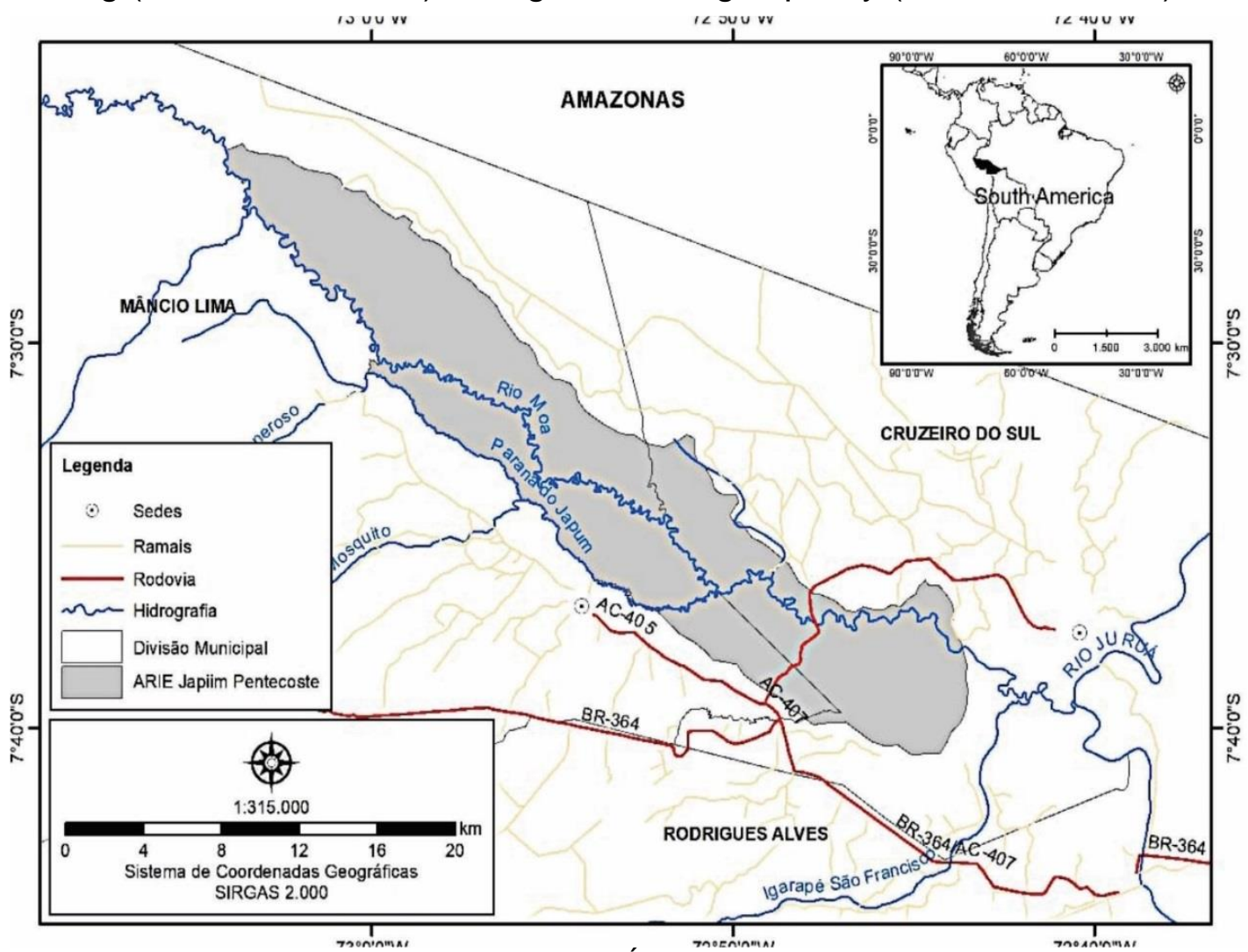

Figure 1: Study region showing the limits of Área de Relevante Interesse Ecológico Japiim Pentescoste, the neighbouring municipalities and roads to access the protected area.

Figura 1: Região de estudo mostrando os limites da Área de Interesse Relevante Ecológico Japiim Pentescoste, os municípios vizinhos e as estradas para acessar a área protegida. 


\section{Protocol application}

We applied the protocol describe above in the Área de Relevante Interesse Ecológico Japiim Pentescostes (hereafter Arie JP), a state protected area located in the Acre State, southwestern part of the Brazilian Amazon (Figure 1). This protected area has practically untouched native vegetation cover, and only fishing activities are common in the region (ACRE/SEMA, 2014A). The main vegetation types found in the Arie JP region are seasonally flooded forests (várzea), covering $98 \%$ of Arie JP area, but there are also white-sand forests and upland forests. Only a small portion $(2 \%)$ of the protected area is deforested (ACRE, 2010; ACRE/SEMA, 2014A).

The Arie JP has 25,750 hectares with $66 \%$ and $34 \%$ of its territory lying within the municipalities of Mâncio Lima and Cruzeiro do Sul, respectively (ACRE/SEMA, 2014A). Arie JP can be accessed either from the state highway AC-405 and secondary roads, or by boat via the Rio Moa (Figure 1). The nearest city, Cruzeiro do Sul, can be reached by the BR-364 federal highway or by air through International Airport Cruzeiro do Sul.

In assessing the attractiveness of the Arie JP avifauna we utilized a bird checklist prepared by EGS for the management plan of this protected area (ACRE/SEMA, 2014B), supplemented by one more recent field work conducted by RP. Field works used standard bird inventory methods, including capture with mist nets, recording of bird vocalizations using professional tape recorder and photography. Sampling was made when birds were most active (i.e., 5:30-11:00 and 15:00-18:30). To obtain a checklist as complete as possible, we sampled all major habitats within the limits of protected area. A detailed analysis of the species checklist will be presented elsewhere.

\section{Results}

\section{Attractiveness of Arie JP avifauna}

We recorded 266 bird species in the Arie JP, distributed in five families (supplementary information) and representing nearly $20 \%$ of the Amazonian avifauna (MITTERMEIER et al., 2003). Most species had low or median levels of attractiveness (Figure 2). However, 30 bird species, or $11 \%$ of total avifauna, attained the highest level of attractiveness for birdwatchers according to our evaluation criteria (Figure 3). 


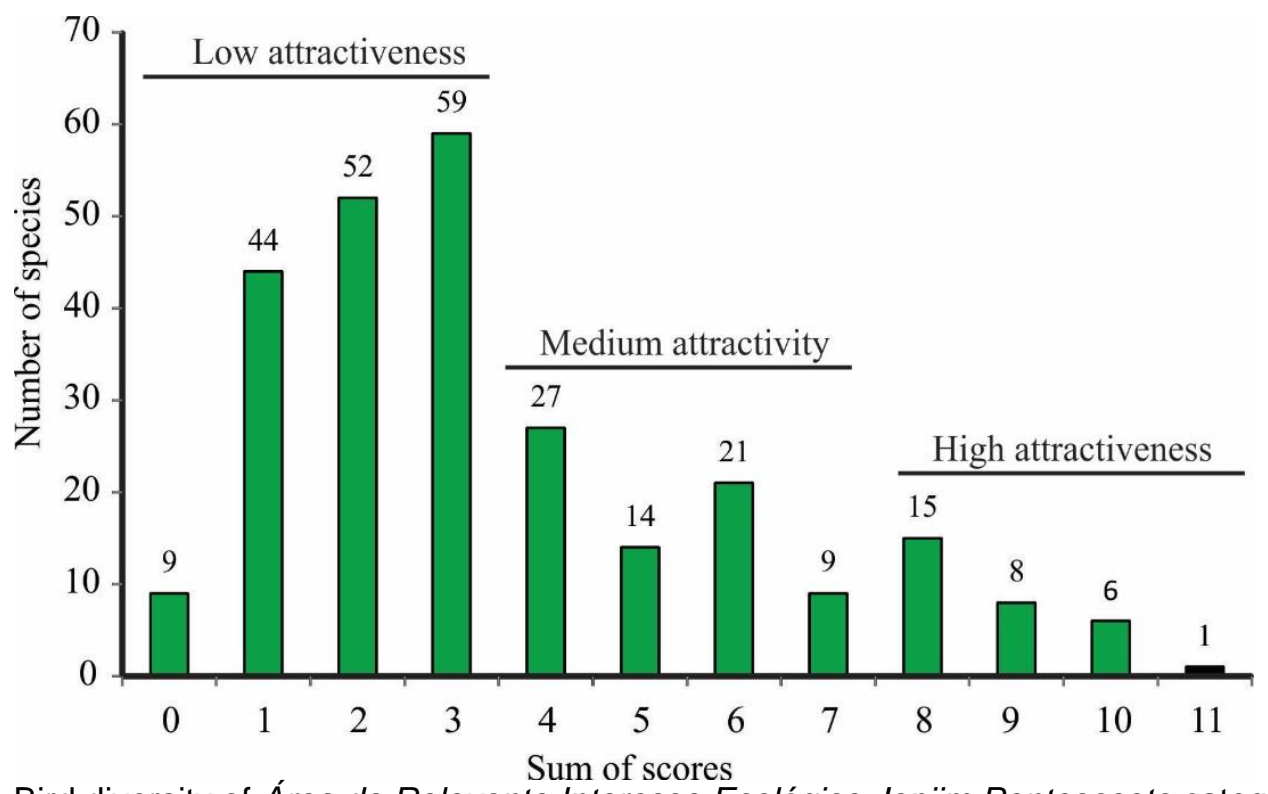

Figure 2: Bird diversity of Área de Relevante Interesse Ecológico Japiim Pentescoste categorized by potential of attractiveness to birdwatchers using the method described in this study.

Figura 2: Diversidade de aves da Área de Interesse Relevante Ecológico Japiim Pentescoste categorizada pelo potencial de atratividade para observadores de aves, utilizando o método descrito neste estudo.
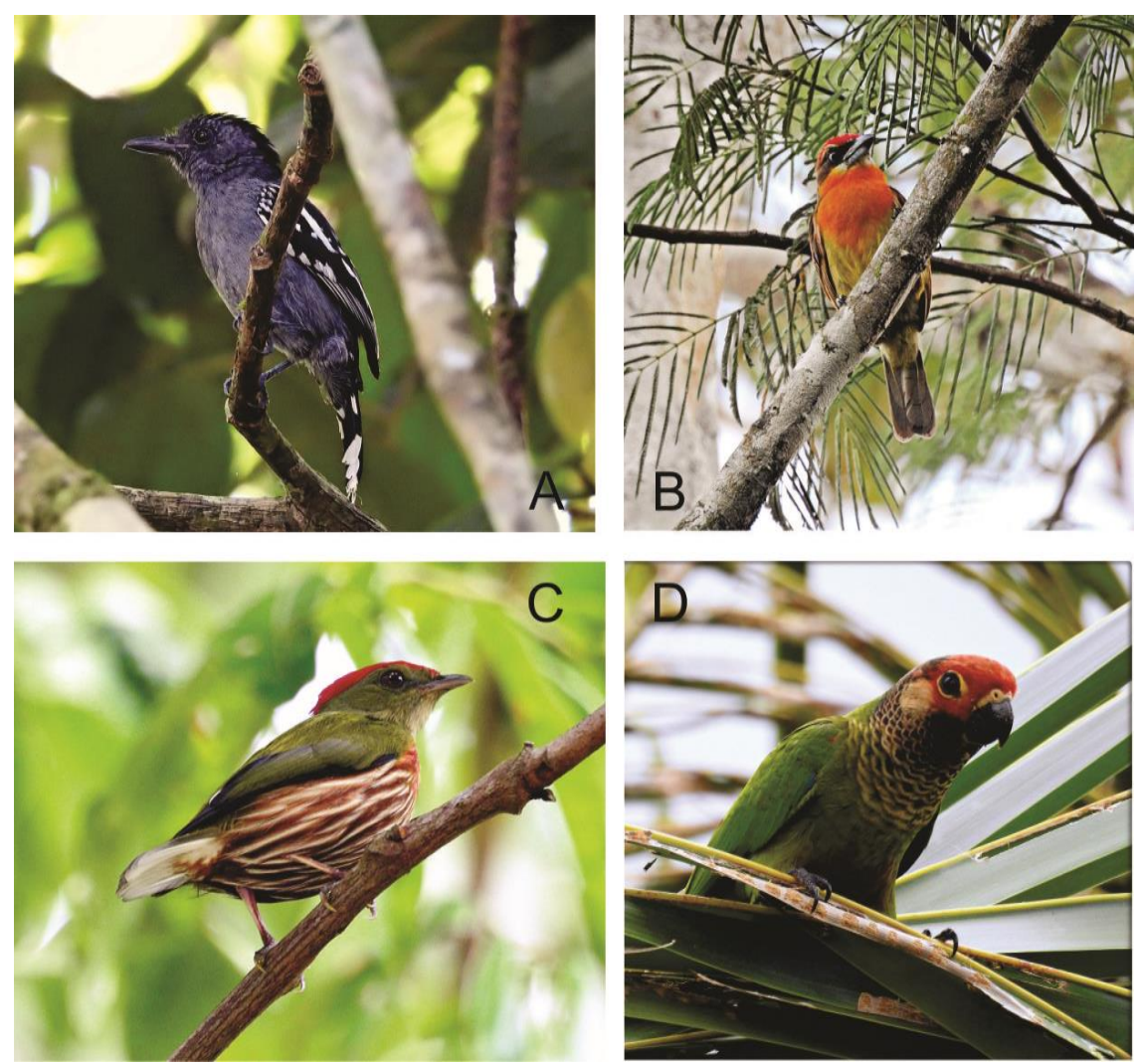

Figures 3: Examples of bird species with low (Thamnnophilus amazonicus A) and high (Capito aurovirens B, Machaeropterus striolatus C, and Pyrrhura roseifrons D) levels of attractiveness for birdwatchers.

Figures 3: Exemplos de espécies de aves com baixo (Thamnnophilus amazonicus A) e alto

(Capito aurovirens B, Machaeropterus striolatus $\mathrm{C}$ e Pyrrhura roseifrons D) níveis de atratividade para observadores de aves. 
Birdwatchers' opinions agreed with our own evaluation for $64 \%$ of the species (Table 1). Considering only species that were less controversial amongst the birdwatchers, this agreement increased to $75.5 \%$ (Table 1). The birdwatchers' evaluation of subsamples of Arie JP bird species was significantly associated with our own evaluation considering the simple majority data ( $\mathrm{G}$ test $=37.13, p<0.0001$ ) or only the $\geq 70 \%$ of birdwatchers consulted in a single category ( $\mathrm{G}$ test $=17.08, p=0.002$ ).

Table 1. Comparisons between the attractiveness of selected bird species of Área de Relevante Interesse Ecológico Japiim Pentescoste measured by the method proposed here and consultation by 20 birdwatchers.

Tabela 1. Comparações entre a atratividade de espécies de aves selecionadas da Área de Interesse Relevante Ecológica Japiim Pentescoste mensuradas pelo método aqui proposto e consultadas por 20 observadores de aves.

\begin{tabular}{|c|c|c|c|c|}
\hline \multirow[t]{2}{*}{ Comparison } & \multirow[t]{2}{*}{$\begin{array}{l}\text { Categories } \\
\text { of interest }\end{array}$} & \multicolumn{2}{|c|}{$\begin{array}{l}\text { Agree with our } \\
\text { evaluation? }\end{array}$} & \multirow[t]{2}{*}{ Totals } \\
\hline & & Yes & No & \\
\hline \multirow[t]{4}{*}{ Simple majority opinions in a single category } & High & 14 & 29 & 43 \\
\hline & Medium & 13 & 9 & 22 \\
\hline & Low & 51 & 6 & 57 \\
\hline & & 78 & 44 & 122 \\
\hline \multirow[t]{4}{*}{ Only $\geq 70 \%$ of opinions in a single category } & High & 11 & 11 & 22 \\
\hline & Medium & 1 & 1 & 2 \\
\hline & Low & 28 & 1 & 19 \\
\hline & & 40 & 13 & 53 \\
\hline
\end{tabular}

\section{Local and regional support to birdwatchers}

The major limitation at Arie JP is the absence of local infrastructure provided by the management institution responsible for the protected area (Table 2). The lack of real monitoring of the public visitation and low availability of local guides are also points of weakness for this protected area (Table 2). Walking trails for displacements of the birdwatchers are available within the reserve, but some distinct habitats cannot be accessed by them. However, proximity to major cities permitted cell phone reception.

The two major towns closest to Arie JP present somewhat differences in the support services available for tourists (Table 2). Proximity to good spots for birding was good for both cities, making it possible for birders to lodge in the cities and access good areas for observing birds within the protected area. However, evaluated lodging facilities, health services and means of transportation ranked better in Cruzeiro do Sul than in Mâncio Lima (Table 2). 
Table 2: Raw scores of indicators used to evaluate quality of support services provided within the limits of Área de Relevante Interesse Ecológico Japiim Pentescoste and neighbouring municipalities relevant for support birdwatchers visiting the protected area.

Tabela 2: Pontuações brutas de indicadores usados para avaliar a qualidade dos serviços de apoio prestados dentro dos limites da Área de Interesse Relevante Ecológica Japiim Pentescostes e municípios vizinhos relevantes para o apoio a observadores de aves que visitam a área protegida.

\begin{tabular}{lccc}
\hline \multicolumn{1}{c}{ Indicators } & Arie JP & Mâncio Lima & Cruzeiro do Sul \\
\hline Walking trails & 2 & & \\
Accommodation infrastruture & 0 & & \\
Communication services & 2 & & \\
Public visitation monitoring & 1 & & \\
Local guides & 1 & & 3 \\
Total score - Protected area & 6 & 3 & 2 \\
\hline Proximity and acessibility to PA & & 1 & 2 \\
Lodging facilites avaliable & & 2 & 1 \\
Time to good birding spots & & 1 & 2 \\
Field guide services & & 1 & 2 \\
Health services & & 1 & $\mathbf{1 2}$ \\
Means of transportation & & 9 & \\
Total score - Municipalities & & & \\
\hline
\end{tabular}

\section{Discussion}

The Amazon biome is the most biodiverse and intact of the great tropical regions of the planet. Unfortunately, Amazon ecosystems are also subject to threats, including an alarming deforestation rate and plans to build hundreds of hydroelectric plants (MACEDO; CASTELO, 2015; FEARNSIDE, 2017). The outstanding biodiversity and ecosystem integrity of the Amazon and its fragility to innumerous threats sources inspired the governments of Amazonian countries to create large and complexes protected areas systems (RAISG, 2017).

However, the successful implementation and long-term viability of these protected areas depends largely on the adequate use and management of the natural resources protected within them. In this context, sustainable tourism represents an important mechanism by which Amazonian protected areas can be consolidated and maintained. This is especially relevant in Brazilian Amazon, where the tourism is permitted and, indeed, encouraged in most types of protected areas (BRASIL, 2000).

Identifying the best ways to implement tourism in protected areas, however, is a permanent challenge to managers. It is important to emphasize that biodiversity could be considered a key resource in the rational use of protected areas (DIAS, 2011). In this sense, bird diversity becomes a highly valuable tool for promoting the sustainable tourism in Amazonian protected areas (PUHAKKA et al., 2011; BERNARDON; NASSAR, 2012). In addition to its outstanding species richness, the Amazonian avifauna is composed by several bird species restricted to areas of endemism distributed across the region (MITTERMEIER et al., 2003). As a result, protected areas located in 
different areas of endemism have their unique bird species composition and, therefore, an enhanced potential to attracted birdwatchers.

Housing a rich and distinctive avifauna, however, is not enough to attract visitors to a specific protected area. Visitors generally have sophisticated expectations; thus, it is necessary to create and improve the logistical conditions for birdwatchers to guarantee that they have a profitable and enjoyable field experience. For these reasons, the viability of tourism in any given protected area needs to be evaluated before it can be planned and implemented. The protocol proposed here is a simple tool to allow managers to quantitatively analyze the potential of their protected areas to attract and receive birdwatchers. The protocol focuses on aspects that we believed are of the major interest to birdwatchers and other users of protected areas.

The more subjective aspect of the protocol is how to evaluate the aesthetic appeal of bird species in terms of morphology and behavior. Although we made some effort to minimize such subjectivity, we felt that this protocol component needs further improvement. However, there were significant overlaps in the bird attractiveness when considering our protocol and the responses to the survey we proposed. Considering the great variability and diversity of motivations of birdwatchers to visit particular regions (MCFARLANE, 1994; SCOTT et al., 2005; GUIMARÃES et al., 2015; CONRADIE et al., 2013), this degree of agreement suggests that protocol works well.

The protocol was effective also in preliminary assessments of the quality of the logistic conditions available within the protected area and in neighboring municipalities. The logistic components analyzed in the protocol could be useful for prioritizing managing actions to improve the capacity of the protected area in receiving and accommodating birdwatchers with different mobility and expectation profiles (MAPLE et al., 2010).

The availability of a preliminary local bird checklist is an essential prerequisite for any manager wishing to apply the protocol. This checklist could be obtained from the original biodiversity assessments conducted by field biologists, which would have been required for management plans for the protected area. Alternatively, managers could consult field guides (PERLO, 2009; RIDGELY; TUDOR, 2009) to compile a list of species potentially occurring in the protected area. However, we recommended that, wherever possible, managers should seek the help of professional ornithologists when constructing a list of bird species for the protected area.

We proposed this protocol assuming that bird-based tourism represents a form of sustainable use of the protected area in question. However, birdwatching activities could potentially have negative impacts on the bird species and populations even within protected areas (STEVEN et al., 2013; LARSON et al., 2016). Thus, although birdwatching-based tourism could be an appropriate alternative for a given protected area, it is necessary to establish procedures for monitoring the activities of birding tourists to avoid, for example, the overuse of specific observation spots or disturbance of individuals and species through the abusive use of play-back (SEKERCIOGLU, 2002). 
The current protocol is a preliminary one, and its use at other protected areas is necessary for its refinement, and to improve its applicability. We believe, however, that the method could be useful to managers in providing a preliminary idea of the potential of birdwatching in protected areas, as well as in highlighting the logistic strengths and weaknesses of a site and so help managers to planning the improvements necessaries to provide a profitable birdwatching experience.

\section{References}

ACRE. Programa Estadual de Zoneamento Ecológico-Econômico do Estado do Acre. Zoneamento ecológico-econômico do Acre Fase II: documento síntese - Escala 1:250.000. 2a Edição. Rio Branco, 2010.

ACRE/SEMA. Plano de Gestão da Área de Relevante Interesse Ecológico Japiim Pentecoste. Produto IV, Fase I. Rio Branco, 2014a.

ACRE/SEMA. Plano de Gestão da Área de Relevante Interesse Ecológico Japiim Pentecoste. Produto II, Volume V. Diagnóstico sobre Ornitofauna (Avifauna) da ARIE Japiim Pentecoste. Rio Branco, 2014b.

ARAÚJO, E.B.; BAIMA, S.; GOMES, M. Quais os planos para proteger Unidade de Conservação na Amazônia? IMAZON. Belem, Pará, 2016. Avaliable in <http://www.imazon.org.br>. Acess in: ago 2019.

BERNARDON, B.; NASSAR, P. M. Birdwatching in the Mamirauá lake as an appeal to ecotourists/birdwatchers. Uakari, v. 8, p. 51-66, 2012.

BONTA, M. Ornithophilia: thoughts on geography in birding. The Geographical Review, v. 100, p.139-151, 2000.

BRASIL. Lei no 9.985, de 18 de julho de 2000. Cria o Sistema nacional de Unidades de Conservação da Natureza e dá outras providências. Avaliable in: <http://www.planalto.gov.br/ccivil 03/leis/L9985.htm> Acess in: 15 ago. 2019.

CARNICELLI-FILHO, S., SCHWARTZ, G. M.; TAHARA A. K. Fear and adventure tourism in Brazil. Tourism Management, v. 31, p. 953-956, 2010.

CONRADIE, N.; VAN ZYL, C.; STRASHEIM, A. What inspires birders to migrate South towards Africa? A quantitative measure of international avitourist motivation. Southern African Business Review, v. 17, n. 1, p.128-167, 2013.

CRACRAFT, J. Historical biogeography and patterns of differentiation within the South American avifauna: areas of endemism. Ornithological Monographs, v. 36, p.49-84, 1985.

DIAS, R. A biodiversidade como atrativo turístico: o caso do Turismo de Observação de Aves no município de Ubatuba (SP). Revista Brasileira de Ecoturismo, São Paulo, vol.4, n.1, p. 111-122, 2011. 
EUBANKS JR, T. L.; STOLL, J. R.; DITTON, R. B. Understanding the Diversity of Eight Birder Sub-populations: Socio-demographic Characteristics, Motivations, Expenditures and Net Benefits. Journal of Ecotourism, v.3, 2004, p. 151-172.

FARIAS, G. B. Observação de aves como possibilidade ecoturística. Revista Brasileira de Ornitologia, v.15, p. 474-477, 2006.

FEARNSIDE, P.M. Deforestation of the Brazilian Amazon. In: H. Shugart (ed.) Oxford Research Encyclopedia of Environmental Science. Oxford University Press, New York, USA, 2017.

GUILHERME, E. Aves do Acre. Rio Branco: EDUFAC. 2016.

GUIMARÃES, M. H.; NUNES, L. C.; MADUREIRA, L.; SANTOS, J. L.; BOSKI, T.; DENTINHO, T.. Measuring birdwatchers preferences: A case for using online networks and mixed-mode surveys. Tourism Management, $v$. 46, p. 102-113, 2015.

HEIMBUCH, J. 10 top birding destinations in the United States. 2015. Avaliable in: <http://www.mnn.com/earth-matters/animals/stories/10-topbirding-destinations-north-america>. Acess in: feb 2020

LARSON, C.L.; REED, S. E.; MERENLENDER, A. M.; CROOKS, K. R. Effects of Recreation on Animals Revealed as Widespread through a Global Systematic Review. PLoS ONE, 11 (12): 1-21, 2016.

MACEDO M.; CASTELLO, L. State of the Amazon: Freshwater Connectivity and Ecosystem Health. In: Oliveira, D., Maretti, C.C., Charity, S. (Eds.), WWF Living Amazon Initiative. Brazil: WWF, 2015.

MAPLE, L. C.; EAGLES, P. F.; ROLFE, H. Birdwatchers' specialisation characteristics and national park tourism planning. Journal of Ecotourism,v. 9, p. 219-238, 2010.

MCFARLANE, B. L. Specialization and motivations of birdwatchers. Wildlife Society Bulletin, v. 22, p. 361-370, 1994.

MEDEIROS, R.; YOUNG, C.E.; PAVESE, H.B.; ARAÚJO, F.F. Contribuição das unidades de conservação brasileiras para a economia nacional: Sumário Executivo. Brasília: UNEP-WCMC, 2011.

MITTERMEIER, R. A.; MITTERMEIER, C. G.; BROOKS, T. M.; PILGRIM, J. D.; KONSTANT, W. R.; FONSECA, G. A.; KORMOS C. Wilderness and biodiversity conservation. Proceedings of the National Academy of Sciences of the United States of America, v. 100, p. 10309-10313, 2003.

PERLO, B. VAN. A field guide to the birds of Brazil. Oxford University Press. 2009.

PUHAKKA L.; SALO M.; SAAAKSJAARVI, I.E. Bird Diversity, Birdwatching Tourism and Conservation in Peru: A Geographic Analysis. PLoS ONE 6(11): 1-14, 2011. 
RAISG. Red Amazónica de Información Sociambiental Georreferenciada. Áreas protegidas e territórios indígenas. 2017. Avaiable in: <https://www.amazoniasocioambiental.org >. Acess in: feb. 2020.

RIDGELY R.S.; TUDOR G. Field guide to the songbirds of South America - the Passerines. Austin: University of Texas Press. 2009.

SCOTT, D.; DITTON, R. B.; STOLL, J. R.; EUBANKS JR., T. L. Measuring Specialization Among Birders: Utility of a Self-Classification Measure. Human Dimensions of Wildlife, v. 10, p. 53-74, 2005.

SEKERCIOGLU, C. H. Impacts of birdwatching on human and avian communities. Environmental Conservation, v. 29, n.3, p. 282-289, 2002.

STEVEN R.; CASTLEY, J. G.; BUCKLEY, R. Tourism revenue as a conservation tool for threatened birds in protected areas. PLoS ONE 8(5): 18, 2013.

STEVEN, R.; MORRISON, C.; CASTLEY, J. G. Birdwatching and avitourism: a global review of research into its participant markets, distribution and impacts, highlighting future research priorities to inform sustainable avitourism management. Journal of Sustainable Tourism, v.23, p. 1257-1276, 2015.

WALLACE, A. R. On the monkeys of the Amazon. Proceedings of the Zoological Society of London, p. 107-110. 1852.

Zar, J. H. Biostatistical analysis. Upper Saddle River, N.J.: Prentice Hall. 1996.

Note:

${ }^{1}$ Conservation Unit is the official term used in Brazil to refer a major category of protected area.

\section{Acknowledgment}

This study is part of the first author master's dissertation in the Management of Protected Area Master's Program (MPGAP/INPA). Mario Cohn-Haft, Cintia Cornelius and Susy Simonetti made several suggestions in the initial stages of the study project. We really appreciate the support of Carminha Arruda and Rita Mesquista from the MPGAP/INPA. We also appreciate the institucional support provided by Secretaria de Estado de Meio Ambiente do Acre (SEMA-AC) currently Secretaria de Estado de Meio Ambiente e das Políticas Indígenas (SEMAPI-ACRE), Instituto Federal do Acre (IFAC), Instituto Chico Mendes de Conservação da Biodiversidade (ICMBIO), Universidade Federal do Acre (UFAC), and Universidade Federal do Amazonas (UFAM).During the execution of this study SHB was a grantee of Fundação de Amparo à Pesquisa do Amazonas through the Programa de Apoio à Fixação de Doutores no Amazonas (Fixam/AM - edital no. 017/2014). Adrian Barnett and Victor Castanho helped with the English. 
Ricardo Antônio de Andrade Plácido: Secretaria de Estado de Meio Ambiente e das Políticas Indígenas (SEMAPI-Acre), Rio Branco, Acre, Brasil. Instituto Nacional de Pesquisas da Amazônia, Manaus, AM, Brasil.

E-mail: ricardoplacido13@gmail.com

Link para o currículo Lattes: http://lattes.cnpq.br/6486983447959385

Edson Guilherme da Silva: Universidade Federal do Acre, Rio Branco, AC, Brasil.

E-mail: guilherme.edson@gmail.com

Link para o currículo Lattes: http://lattes.cnpq.br/8706546776725905

Sérgio Henrique Borges: Universidade Federal do Amazonas, Manaus, AM, Brasil.

E-mail: shborges9@gmail.com

Link para o currículo Lattes: http://lattes.cnpq.br/7481940705014110

Data de submissão: 16 de setembro de 2020

Data de recebimento de correções: 03 de agosto de 2021

Data do aceite: 03 de agosto de 2021

Avaliado anonimamente 